\title{
The politics of « racial » classification in Brazil
}

\section{Peter Fry}

\section{(2) OpenEdition}

\section{Journals}

Electronic version

URL: https://journals.openedition.org/jsa/11108

DOI: 10.4000/jsa. 11108

ISSN: $1957-7842$

\section{Publisher}

Société des américanistes

\section{Printed version}

Date of publication: 5 December 2009

Number of pages: 261-282

ISSN: 0037-9174

\section{Electronic reference}

Peter Fry, "The politics of « racial » classification in Brazil", Journal de la Société des américanistes

[Online], 95-2 | 2009, Online since 10 December 2014, connection on 02 September 2022. URL: http:// journals.openedition.org/jsa/11108 ; DOI: https://doi.org/10.4000/jsa.11108

All rights reserved 


\title{
THE POLITICS OF « RACIAL » CLASSIFICATION IN BRAZIL
}

\author{
Peter FRY *
}

This paper traces the genealogy of " racial » taxonomies in Brazil arguing that recent policies which focus on the " black population » or the "black community » depend upon a belief that Brazilian society is neatly divided into " blacks " and " not blacks ", thus superseding taxonomies which produce ambiguous « racial » categories based on the social " appearance " of individuals. The paper argues that such new political orientation may be a form of self fulfilling prophecy, bringing into being that which it assumed to exist. [Key words: race, Brazil, affirmative action.]

La politique de classification " raciale » au Brésil. Cet article retrace la généalogie des taxinomies « raciales » au Brésil, et démontre que les récentes politiques publiques en direction de la «population noire» ou de la "communauté noire » reposent sur la croyance que la société brésilienne est clairement divisée entre "noirs » et «nonnoirs ». Ces politiques remplacent ainsi des taxinomies produisant des catégories « raciales » ambiguës fondées sur l'« apparence » sociale des individus. L'article montre qu'une telle orientation politique s'apparente à une prophétie auto-réalisatrice, amenant à être ce qui est supposé exister. [Mots-clés: race, Brésil, discrimination positive.]

Las políticas de clasificación « racial » en Brasil. Este artículo traza la genealogía de las taxonomías « raciales » en Brasil argumentando que las recientes políticas aplicadas a la " población negra » o a la " comunidad negra » parten del presupuesto de que la sociedad brasileña se divide nítidamente entre « negros » $\mathrm{y}$ « no negros », suprimiendo, así, taxonomías que producen categorías « raciales » ambiguas basadas en la " apariencia » social de los individuos. El artículo argumenta que esta orientación política se asemeja a una profecía auto-cumplida, estableciendo lo que se presupone que ya existe. [Palabras clave: raza, Brasil, acción afirmativa.]

\section{THE QUESTION}

The very first law that introduced racial quotas in Brazilian universities was enacted in November 2001 by the state legislature of Rio de Janeiro. Apart from

* Professor of Anthropology, rua Voluntários da Pátria, 34, casa 15, Rio de Janeiro 22270-010, Brasil [phfrio@gmail.com].

Journal de la Société des Américanistes, 2009, 95-2, pp. 261-282. (C) Société des Américanistes. 
the $50 \%$ quota for candidates who had studied in public schools which had been enacted a few months previously, this new law reserved $40 \%$ of all places in Rio's state-owned universities for negros or pardos ${ }^{1}$. From the beginning the Rio authorities were concerned with the best way to classify candidates into these « racial » categories. After consulting « authorities » (myself included), it was decided that there were no objective criteria for defining a person's race. The method, therefore, would be self classification. Candidates for the 2002 entrance exam were obliged to fill in a form which asked among other things the candidate's « race ». Question 24 reads thus: « In accordance with decree n.30.766, of $04 / 03 / 2002$, I declare, under penalties of the law, that I identify myself as negro or pardo: () Yes/() No ". If the candidate did not tick one of the boxes, the instructions for filling in the form explained, he or she would be considered branco. Quite clearly, then, candidates were obliged to classify themselves in one of two categories: negro or pardo versus branco eligible or not for the racial quotas. Later the law was changed, the racial quotas were reduced to $20 \%$ and candidates were asked whether they were negro or not. No longer were they asked if they were pardo.

There were many problems. More than 300 candidates filed suit claiming that they had lost their places to blacks or public school candidates with lower scores. One candidate, who refused to fill in question 24 because he was against the quota system, failed to enter the faculty of law although he claimed that he would have done so if he had declared himself negro. Candidates that seemed pretty branco were interviewed on TV claiming African ancestry. The Coordinator of the NGO Educafro which prepares young negros for the entrance exam, Frei David, accused the State University of Rio de Janeiro (UERJ) of permitting « frauds ».

It was probably to avoid this kind of problem that the University of Brasília opted for photographs and commissions. In June 2004, under rules introduced that year, candidates for the University of Brasilia's entrance examination formed two queues: one for those competing for the $20 \%$ of places reserved for negros and one for the rest. Those claiming to be negro had their photographs taken: on the basis of these pictures a commission dubbed a "racial tribunal » in a recent article (Maio and Santos 2005), composed of a student, a sociologist, an anthropologist and three representatives of Brazil's Black Movement, decided whether they were really black or not. The commission rejected 212 out of 4,385 . 34 of these complained, and were interviewed by a second commission, composed of university teachers and members of non-governmental organizations, which asked among other things whether they had strong links to « black values and culture ». One young man said afterwards that they asked him whether he had belonged to the Black movement and if he had ever had a mulata girl friend. In the end only 13 of the 34 were denied a black identity.

Many Brazilian intellectuals expressed some astonishment that one of the leading universities in the country could have adopted racial classification tech- 
niques redolent of the eugenics movement of the 1930s. Others wrung their hands at what they saw as an affront to Brazil's identity as a mestizo republic where racial identity was formally immaterial. Defenders of the newly introduced quotas maintained that Brazil must break with its French republican tradition of colour-blindness. Unequal treatment was necessary, they argued, for those who were, in fact, unequal. To treat all equally was the only way of avoiding dealing with racial inequality (Fry 2004; Maggie and Fry 2002; Maio and Santos 2005; Santos 2004).

But the debate concerned not only problems of classification, but also of taxonomy, the classificatory system itself. On the one side, there were those who pointed to centuries of "miscegenation " to argue that the introduction of a bi-racial taxonomy would lead to the formation of opposing racial groups in Brazil with the risk of bringing about racial hatred and strife. The defendants of the quotas argued that Brazil has always been in fact divided into negros and brancos, the latter discriminating against the former (" ask any policeman ", was a common comment) (Sales 2006), but that this underlying taxonomy had been masked by " miscegenation » and the myth of racial democracy. On the face of things, the dispute is simply between those in favour of affirmative action and those contrary to it. I would argue, however, that underlying this political confrontation is a dispute over taxonomies; on the one hand taxonomies with multiple categories, and on the other a simple bipolar taxonomy of negros and brancos.

In this paper I wish to reflect on the genealogy of Brazilian racial taxonomies as a way of better understanding what is at stake during the present debate on affirmative action and reparation.

\section{TAXONOMIES AND CLASSIFICATIONS}

De quelques formes primitives de classification. Contribution à l'étude des représentations collectives [QFPC] (Durkheim and Mauss 1968) as is well known is the classic text announcing the social genesis of systems of classification.

Loin que l'on soit fondé à admettre comme une évidence que les hommes classent tout naturellement, par une sorte de nécessité interne de leur entendement individuel, on doit, au contraire, se demander qu'est-ce qui a pu les amener à disposer leurs idées sous cette forme et où ils ont pu trouver le plan de cette remarquable disposition. (ibid., p. 18)

The reply is, of course, society: "Le centre des premiers systèmes de la nature, ce n'est pas l'individu; c'est la société " (ibid., p. 87). "La société n'a pas été simplement un modèle d'après lequel la pensée classificatrice aurait travaillé; ce sont ses propres cadres qui ont servi de cadres au système. Les premières catégories logiques ont été des classes d'hommes dans lesquelles ces choses ont été intégrées. 
C'est parce que les hommes étaient groupés et se pensaient sous forme de groupes qu'ils ont groupé idéalement les autres êtres, et les deux modes de groupement ont commencé par se confondre au point d'être indistincts » (ibid., p. 83).

However, as so many have noted, the causal explanation of Durkheim and Mauss suffers from petitio principii. How may one derive the logic of a classificatory system from society if social organization itself requires mental categories to exist as such? Avoiding petitio principii, we part from the principle that the social order is itself fashioned through the dispute over alternative systems of classification.

This critique of QFPC is particularly relevant to the exercise in hand, for rather than taking as our object of analysis classificatory forms of things, we are concerned with understanding the ways in which members of society themselves come to be classified in "racial » categories. More than is the case with the classification of things, the criteria for constructing taxonomies to classify individuals result in political, economic and existential consequences for the individuals thus classified. It was surely not by chance that Robert Hertz (1980) drew attention to the analogy between the relationship between the two hands and the relationships between sexes and races. The classification of the hands as superior and inferior had, he claimed, the effect of exacerbating whatever differences nature may have given them. The discussion of racial taxonomies is not a purely technical or logical exercise, as for example, is the discussion on the classification of colours in nature (Sahlins 1977). To discuss the colour of people is to enter a complex world of emotions: feelings of guilt and remorse, of anger for past and present suffering, which are in large part derived from the taxonomies and classifications in dispute.

Our use of taxonomies and classifications in the plural reveals another problem in using QFPC as a theoretical starting point. Durkheim and Mauss sought the sociological principles of classification through an understanding of what they saw as the most elementary societies. QFPC follows an evolutionary schema, beginning with the extreme simplicity of the aborigines of Australia, then North American India societies, Chinese society and finally modern France. All these societies are treated as coherent and systematic entities, whose systems of classification are shared by all. Our challenge, as we look at contemporary Brazil, is to understand a situation in which more than one racial taxonomy exist, each claiming truth, legitimacy and naturalness.

One might argue therefore that QFPC is of little help for this exercise. However, in one absolutely crucial way, QFPC establishes a starting point which opens possibilities for an analysis of what we see as taxonomies in dispute. Durkheim and Mauss taught that systems of classification which have their origin in society, project themselves as belonging to the natural order of things. We must therefore search for the mechanisms through which racial taxonomies acquire their " naturalness » through time, and, above all, understand how the 
bipolar taxonomy became sufficiently strong to be adopted by the State as a basis for affirmative action.

A study of this dispute should allow for the suggestion of the possible dialectical relations between taxonomies and subjectivities (both individual and collective). Each requires and at the same time engenders the other. By so doing, it should be possible to delineate possible political, economic and moral consequences for society of the relative preponderance of one or the other

\section{EARLY PERPLEXITIES}

The colours of people, or if one prefers, the appearance of people have always been the subject of perplexity not only for Brazilians themselves but especially among visitors. One of the most often quoted of such visitors is Joseph Arthur Gobineau (1816-1855). After writing his Essai sur l'inégalité des races humaines (1853-1855), he landed in Brazil in the middle of the 1869 carnival. He was horror struck by what he saw as excessive "racial mixture ", which he thought would condemn Brazil to ultimate doom. Gobineau described a society - Brazil - in which « not one Brazilian has pure blood since examples of marriages between Whites, Indians and Blacks are so disseminated that nuances of colour are infinite, which leads to the most depressing degeneration as much among the lower as among the upper classes » (Skidmore 1993). Gobineau was the most radical critic of Brazil's mixture; he found only one exception to the general rule: the family of the Emperor, Dom Pedro II.

Brazilian writers noted the predominance of mixture. In his essay As raças humanas e a responsabilidade penal no Brasil (1897), the professor of forensic medicine at the Faculty of Medicine of Bahia Nina Rodrigues described the situation in these terms:

Prima facie, it is possible to distinguish within today's Brazilian population a significant majority of mestizos in various degrees of corssing [sic] and a minority of pure uncrossed anthropological elements. [in a footnote he adds: « the term pure has here only a relative value which merely exists in contrast with the mixing which we observe.] (Rodrigues 1894, pp. 89, 90; author's translation) $^{2}$

He distributed the mestiços in four categories, each one defined by the degree of mixture involved:

1) The mulattos, « product of the crossing of the White with the Black, a very numerous group constituting almost the total population in certain regions of the country » (ibid., p. 91; author's translation) ${ }^{3}$. He further divides the mulattos in " mulatos dos primeiros sangues " (mulattos of first bloods), " mulatos claros » (light mulattos) and " mulatos escuros » (dark mulattos);

2) The mamelucos or caboclos, "produto do cruzamento do branco com o indio » (product of the crossing of the White with the Indian) (ibid., p. 91); 
3) The curibocas or cafuzos, "produto do cruzamento do negro com o índio " (product of the crossing of the Black with the Indian) (ibid., pp. 91, 92).

4) The pardos, " product of the crossing of the three races but predominantly from the crossing of the mulatto and the Indian, or with mamelucos caboclos. This mestizo, which, in the case of an equivalent mixture of the three races, must be the Brazilian product par excellence, and much more numerous that one might suppose » (ibid., p. 92; author's translation) ${ }^{4}$.

These observers of Brazilian social life at the turn of the twentieth century constructed a taxonomy whose logic was given by three principal categories (the White, Black and Amerindian " races »), which, in their mixture, produce subsequently derived intermediate categories. Mutatis mutandis, this schema informed the analyses of most subsequent Brazilian anthropologists during the first decades of the twentieth century. Roquette-Pinto, for example, divided the population into four " types »: the brancos or leucodermos; the negros, or melanodermos; the mestiços, or faiodermos; and the cafuzos, or xantodermos. What distinguished these theoreticians was less their classificatory schemes and more their prognosis for the future of Brazil. While for Gobineau racial mixture would lead to Brazil's ultimate ruin (he predicted that the society would cease to exist in about 200 years), Roquette-Pinto and his followers denied any hereditary or constitutional problems deriving from « miscegenation " 5 .

The first Brazilian censuses reflected in part these taxonomies. The first national census of 1872 was based on a taxonomy of four categories: branco, preto, pardo and caboclo (Amerindians). The second census of 1890 substituted pardo for mestiço, in the belief that the colour pardo referred only to the offspring of marriages between brancos and negros. The 1920 census eliminated the item " race » altogether because it was felt that " replies greatly concealed the truth », above all the replies of the mestiços (Carvalho 2004). Even so, in common parlance the population was more simply divided into brancos and homens de cor (people/men of colour). At this early stage in the coining of "racial » taxonomies, therefore, a binary system existed alongside a more complex taxonomy of at least four categories. As Armelle Enders pointed out in her critique of this paper; many 19th century travellers to Brazil, "beaucoup moins obsédés que Gobineau par la question raciale, ont l'impression, en arrivant à Rio de Janeiro, de débarquer en Guinée. Edouard Manet, qui passe quelques semaines dans la ville en 1849 (à la fin de la période intense du trafic négrier), distingue entre, d'un côté, les Noirs et les métis (mêlant déjà les deux catégories) et, de l'autre côté, les "Brésiliens". Le Brésil de la première moitié du XIX ${ }^{2}$ siècle n'est mullement un "pays métis", mais une société très cloisonnée où la couleur de la peau correspond quasiment à un statut juridique » (Enders 2006, personal communication). 


\section{BRAZIL'S FAME AS A HYBRID BRAZIL WITH « RACIAL 》 HARMONY INSPIRES THE WORLD}

The Brazilian modernists, following the same taxonomy of races and their mixture shared Roquette-Pinto's optimism. For them, hybridism was not the weakness of the country; rather its strength, celebrated in the art of Tarsila, Anita, Portinari and di Cavalcanti and in the literature of Mário and Oswald de Andrade. Mario de Andrade's Macunaíma was born negro of an Indian single mother whose other children covered the rest of the spectrum, and became branco when he migrated to the metropolis (Maggie 2005). Gilberto Freyre (1933) described Brazil in terms of basic antagonisms between the great houses and the slave quarters, the bourgeois town houses and the shanties, grand tombstones and open graves, masters and slaves, brancos and negros. He argued that these antagonisms were mediated and attenuated by the erotic encounters between members of one and other pole. This led to his utopian vision of a Brazil which would finally overcome its antagonisms when all was dissolved into a homogeneous " meta-raça ".

This optimistic understanding of a hybrid Brazil without « pure races » and without racial hatred excited the imagination of many, not least the anthropologists of Columbia University in New York and UNESCO's intellectuals who were avid to find pacific solutions for multi-racial societies in the years following the Second World War (Maio 1997). The research carried out under the auspices of UNESCO reproduced to a certain degree the previous taxonomies recognizing a few brancos and negros and a vast mass of mestiços. But there was a fundamental difference also. In accordance with the insights of the São Paulo sociologist Oracy Nogueira (1991), the categories of Brazil's taxonomy were not to be understood in terms of descent (origem) as in the United States of the " one drop rule ", but in terms of appearance (marca). Other participants in the UNESCO team followed suit. Marvin Harris, for example, provides this description of the people of Minas Velhas based entirely on their physical attributes:

Les types les plus courants sont le moreno, le chulo, le mulato, le creolo et le cabo verde. Le moreno a les cheveux ondulés et la peau d'un Blanc fortement hâlé. Le mulato a les cheveux crépus et frisés, et la peau plus foncée que le moreno. Le chulo a les cheveux crépus et bouclés et la peau " de la couleur de caramel ou de tabac ». Le creolo a les cheveux fins et ondulés et la peau presque aussi foncée que le chulo, mais plus lisse. Le cabo verde a les cheveux plats, mais la même couleur de peau que le Noir: (Harris 1951, p. 60)

However fascinated they may have been with Brazil's complex « racial» taxonomy, the authors of Races et classes dans le Brésil rural (Wagley 1951), also noted the presence of a basic logical and socio-economic opposition between brancos and pretos which coincided with the opposition between the rich and the 
poor. Marvin Harris illustrated his vision of Minas Velhas using a triangle based on a trapeze. In the diagram he drew, the population was divided into brancos and ricos who occupied the superior positions of the triangle, while the pretos or pobres occupied the lower part. By so doing, Harris (1951, p. 86) established the logical relation preto:branco::pobre:rico. Even so, this clear opposition was not deemed present in the political domain. The words of Marvin Harris and another of the Brazilian participants in the UNESCO project, Luiz de Aguiar Costa Pinto (1953), are clear:

Objectively, there is a correspondence between class and race in Brazil [...]; the more negroid the phenotype the lower the class. Prevention of the development of racial ideology may very well be a reflex of the conditions which control the development of class confrontations. In the United States, racism and racial caste divisions have split and fragmented the lower class. " Black Power » in the United States lacks the revolutionary potential of the preponderant mass; "Black Power " in Brazil contains this potential. The ambiguity built into the Brazilian calculus of racial identity is thus, speculatively at least, as intelligible as the relative precision with which Blacks and Whites identify each other in the United States. (Harris 1970, p. 85)

Thus if it be true, as Myrdal suggests, than on the day when the trades unions of the United States expunge the colour line from their ranks in the name of class solidarity, this will produce an explosion which will be heard in the entire world and will lead to a change of direction which will surprise North American civilization, also here one might say, in the light of current opinion in the world in relation to the racial situation in Brazil, that a no lesser explosion will be produced in Brazil if one day the great masses of colour of this country lend their ears to the callings of this race ideology and charge forward along the cul-de-sac which it leads to. (Costa Pinto 1953, p. 291; author's translation) ${ }^{6}$

For both these writers, then, the " ambiguity " of Brazil's racial calculus stands opposed to the clarity of racial identities in the Unites States as class is to race as a principle of mass political action in one society as opposed to the other. Even so, as at the turn of the century which saw a dichotomy of brancos and homens de cor; so the UNESCO researchers recognized the coexistence of bipolar and more complex « racial » taxonomies.

\section{BRAZIL BECOMES A LAND OF RACIAL DISTINCTION AND DISCRININATION}

Most subsequent sociological analyses, with the exception of Carl Degler (1986) who posited that the category mulatto served as a kind of "safety valve " which secured the system of racial domination, have underplayed the ambiguity of hybridism to concentrate on what is seen as a fundamental opposition between negros and brancos. Ironically it was Costa Pinto who first described the demography of Rio de Janeiro in terms of Whites and people of colour. He presented his findings in the form of simple bar diagrams. 
The hierarchy of races and classes as in Harris' diagram gave way to the depiction of a society cruelly divided into two clear and separate categories. While the triangles ritualize hierarchy and relationship, the bar diagram ritualizes a society divided into two distinct collective identities. Contrary to Nina Rodrigues's prophecy that Brazil would ultimately become a society of mestiços, it had become in the sociologists' imagination a society divided into two and only two racial categories. Costa Pinto's diagram informs, reifies and ritualizes a bipolar taxonomy.

How did Costa Pinto construct his diagram? At the time of his research, the Brazilian Geographical and Statistical Institute (IBGE) utilized a four-category taxonomy to establish what they determined as colour: branca, parda, preta, and amerela. (Today it includes one more category: indigena for Amerindians ; Nobles 2002). What Costa Pinto did was to group together those who declared themselves pardo or preto to form a new inclusive category which he denominated, reverting to the turn of the century terminology, " de cor ", " of colour »:

Costa Pinto's elision of the categories pardo and preto soon became standard practice in Brazilian sociology as can be seen in such titles as Brancos e Negros em São Paulo (Bastide and Fernandes 1971), and A integração do negro na sociedade de classes: o legado da "raça branca" (Fernandes 1978b). But the practice acquired greater authority with the publication in 1979 of sociologist Carlos Hasenbalg's Discriminação e desigualdades raciais no Brasil (Hasenbalg 1979), which was to have great impact on the Black Movement and on subsequent sociology. He effected statistically that which the black movement had been unable to do in practice, transforming Brazil's complex taxonomy (what he calls the « colour continuum ») into a simple dichotomous one. In the first chapter of Discriminação e desigualdades raciais no Brasil census data are presented utilizing the categories of pretos, pardos e brancos. But in the later and most important chapters of the book, those which analyse political and social mobility (or the lack thereof), Hasenbalg elides the two categories into one which he calls «non-Whites». In an article first published in 1985, Hasenbalg justifies this procedure:

Non-whites are defined as the sum of what the various censuses classify as Blacks [pretos] and Browns [pardos], excluding the category yellow [amarelos]. In all dimensions analysed, the browns occupy an intermediary position between the whites and the blacks, although this position is always closer to that of the Blacks. (Hasenbalg 1988; author's translation $)^{7}$

As if by magic the continuum had become a dichotomy. But how often is the cool reason of « methodology » in effect the product of the cultural categories of its author? Hasenbalg, as Florestan Fernandes before him, saw himself as a significant ally of the black activists, for whom the division of the Brazilian population into Whites and non-Whites had been their point of departure and 
the dreamed-of future. After all what is a black movement without Blacks, and, by logical opposition, Whites?

In retrospect, I would argue that Discriminação e desigualdades raciais no Brasil became an ideological narrative for the black movement and its sympathizers much as Casa Grande e Senzala had been for the modernists of the 1930s. At the end of his book he makes this point quite explicitly:

If processes of social competition and individual social mobility based on market forces operate to the detriment of the racially subordinate group, the analysis should focus on the forms of political mobilization of the non-Whites and to inter-racial conflict. The effect of race on the class structure and the evolution of racial inequalities will depend on the emergence of racial movements and of the forms they take as well as the way in which they relate to other battles and other social movements. (Hasenbalg 1979 , p. 221; author's translation) ${ }^{8}$

More recently and in preparation for Brazil's participation in the III World United Nations conference for the combat against racism, racial discrimination, xenophobia and correlate intolerance in Durban in October, 2001, the Brazilian government's Institute for Applied economic Research (IPEA) presented a paper which has had enormous influence on the debate over the racial question in recent years. Once again, Brazilian society is imagined as made up of only two « racial groups » and the diagrams, now much more sophisticated due to computer technology, are redolent of Costa Pinto's.

Thus, statistical analysis has come to the aid of the bipolar taxonomy, eliminating for ever intermediate categories. This form of understanding Brazil, which José Murilo de Carvalho has appropriately called «statistical racial genocide » effectively substitutes the complex taxonomy of the IBGE with a simple bipolar one.

It is obvious to anyone that the $39 \%$ of pardos in the 2000 census to a large extent are made up of people descended from Indians. There lies, it must be said, the raison d'être of the racial tribunal of the University of Brasilia which is charged with distinguishing people of African descent from among the pardos. The monthly research bulletin of the IBGE in 1998 showed that people who were classified as pardos according to the imposed categories of the Institute called themselves morenas (brown) or morenas claras (light brown) in $60 \%$ of the cases when left free to define themselves as they wished. Only $34 \%$ of the pardos agreed with the Institute's taxonomy and only $2 \%$ defined themselves as mulattos. Research conducted in the Metropolitan Region of Rio de Janeiro in 1997 revealed that $50 \%$ of those classified as pardos by the interviewers said that they were brown or white. Another research project carried out in Rio in 2000 showed that $48 \%$ of the pardos claimed Indian ancestry. In the northern states, where there was much less African slavery, those descended from Indians form without any doubt the great majority of the pardos. (Carvalho 2004, p. 7; author's translation) ${ }^{9}$

Qualitative analyses have also steadily abandoned the gradations and ambiguities so prevalent in the UNESCO research. This new tradition seems to have 
begun with the São Paulo sociologist Florestan Fernandes, who also participated in the UNESCO project as Roger Bastide's assistant, and who, quite explicitly adopted as analytical terms the categories used by his " natives », his black activist friends:

We found various difficulties in the use of certain words. The term " preto » was always used by the " white » to designate the negro and the mulatto in São Paulo, but calling up a stereotyped and highly negative image socially elaborated in the past. The negros and mulattos themselves preferred, in their first manifestations of autonomy - through protest movements - the self description contained in the word negro. On the other hand, they impugne the word "white», arguing that miscegenation imposes severe restrictions on the pretensions of those paulistas who claim " racial purity ". To avoid susceptibilities or recriminations we utilize the word " preto " when stereotyping by the "Whites » is evident and we put all the words in inverted commas, except for concrete cases where we could discern the gradations of skin colour of the subjects under investigation. Otherwise we use the expressions « men of colour » and " population of colour » quite frequently and with no pejorative intention. (Fernandes 1978a, p. 25; author's translation) ${ }^{10}$

In this way, the native categories of the black activists (brancos and negros) became the analytical categories of native Brazilian sociology. Needless to say, most American researchers, whose native and analytical categories tend to be based on the bipolar taxonomy which is dominant in North American society, have merely reinforced this tendency ${ }^{11}$.

\section{THE LAIV AND THE BUILDING OF A BIPOLAR TAXONOMY}

Another important factor in the naturalization of a Brazil of negros and brancos is the fight against racial discrimination which at first sight might appear to negate the existence of races but in practice confirms the existence of but two. Costa Pinto clearly perceived this demarche in his analysis of the passing of the Almino Afonso law against racial discrimination in 1951, arguing that for the first time in Republican law the negro appears as a juridical entity as Brazil is imagined as a nation of white discriminators and black victims:

[The law represents] the beginning of a process which, in the context of the racial tensions which exist and which are becoming more serious in the country, will not surprise us if they lead to the situation which is characteristic of the southern cities of the United States and which may be resumed by the formula separate but equal. In fact, until the new law, in Brazil with its republican legislation, the negro appeared as a free man in 1888 , as a citizen, in the abstract, juridically equal to all other citizens. He was in the Law by exclusion - all are equal before the law, independently of colour, sex, religion, etc. Now, for the first time, unless I am mistaken, a law has been passed which defines the behaviour of Whites in relation to blacks, and attributed to the latter, as 
negros, the specific right not to be denied some more general rights which the law already attributed to all citizens regardless of their ethnic condition. [...] and to declare that those who violate principles already solemnly present in more general prior legislation are punishable. (Costa Pinto 1953, pp. 292-293; author's translation) ${ }^{12}$

He then goes on to suggest that such legislation may be the prelude for effective segregation:

Such a law could come to be the prelude for subsequent legislation which would substitute it, inspired by the desire to remedy its practical defects, assuring both Blacks and Whites of the right to receive education, recreation, residential districts, social services and other institutionalised sectors of social life equal but separate. For this to come about, one of the pre-conditions now exists: the juridical entity negro, present in the spirit and text of the common Law. (ibid.; author's translation) ${ }^{13}$

More recently, Fabiano Dias Monteiro has argued forcefully that this law which so many of us had understood as purely anti-racist constitutes in effect the truth of a bipolar racial taxonomy. It was precisely in the field of the law and the concomitant fight against the " farce of racial democracy » that the black movement was able to strengthen the notion of a racially divided Brazil, what he denominates the Brazilian racial schism (Dias Monteiro 2003).

A further step in the strengthening of the legal recognition of a black identity (and by logical extension a white one also) and therefore in the strengthening of a bipolar racial taxonomy was the 1988 Constitution, which defined racism as a crime with no time limit and without possibility of bail, as opposed to being simply a " contravention » as it had been defined under the Afonso Arinos law. The 1988 Constitution also introduced the concept of " communities that are descendants of maroon communities (quilombos) ", with rights over titles to their lands. This effectively divided the non-Indian rural population in negros and not negros; in quilombolas and the rest. But it was during the Fernando Henrique Cardoso government (1994-2002) that more direct measures were taken. In 1995 the government launched its National Human Rights Program which contained a series of planned activities in the interests of the " black community ». These included support for « the inter-ministerial working group - created by Presidential Decree on November 20,1995- for drawing up activities and policies to recognize the value of the black population », and a "Working Group for the Elimination of Discrimination in the Workplace and in Careers » within the Ministry of Labor. In relation to the legal system, the Program proposed to « stimulate State Secretaries of Public Security to promote refresher courses and seminars on racial discrimination. [...] Adopt the principle of the criminalization of racism in the Penal Code and Penal Process. [...] Disseminate the International Conventions, articles of the Federal Constitution and infra-constitutional legislation dealing with racism. [...] Support the production and publication of documents contributing to dissemination of anti-discriminatory legislation $»$. 
The document also suggested the inclusion of racial data in all official documents, the stimulation of the presence of «ethnic groups that make up our population » (grupos étnicos que compõem a nossa população), in institutional propaganda, and "private initiatives to bring about positive discrimination » (ações da iniciativa privada que realizem discriminação positive). It also recommended the implementation of " affirmative action for the access of negros to professional and university courses and to cutting edge technology » (ações afirmativas para o acesso dos negros aos cursos profissionalizantes, à universidade e às áreas de tecnologia de ponta), and the formulation of « compensatory policies that promote the black community socially and economically " (politicas compensatórias que promovam social e economicamente a commidade negra) (Programa Nacional de Direitos Humanos [PNDH], 1996, my emphasis). The PNDH also proposed that the IBGE eliminate the categories pardo and preto in favour of one single category negro. Most of these ideas remained on paper. It was to be the government of President Luis Inácio Lula da Silva which came to power in 2002 which took them one stage further.

The Lula administration gave greater salience to the issue of race by creating the Special Secretariat for Policies for the Promotion of Racial Equality (SEPPIR) under leadership of Matilde Ribeiro with the status of Minister of State. SEPPIR was charged with: promoting « equality and protection of the rights of individuals and racial and ethnic groups subject to discrimination and other forms of intolerance, with emphasis on the black population ") ( $a$ igualdade $e$ a proteção dos direitos de indivíduos e grupos raciais e étnicos afetados pela discriminação e demais formas de intolerância, com ênfase na população negra); articulating, promoting and following through « various programmes involving cooperation with public and private organisms, both Brazilian and foreign » (diversos programas de cooperação com organismos públicos e privados, nacionais $e$ internacionais); promoting compliance with the international conventions to which Brazil is signatory, and which refer to the " promotion of equality and combating racial or ethnic discrimination »; and " aiding the Ministry of Foreign Affairs in coming closer to the nations of the African continent $"{ }^{14}$.

This tiny Secretariat with a staff of less than forty has been extremely active in making itself felt in various ministries and in State and municipal governments, encouraging policies directed to negros principally in the fields of health and education. It has also lent its weight to two governmental projects which, if implemented, would definitively install a bipolar racial taxonomy in Brazil. The first is a bill which seeks to implement racial quotas in all federal institutions of higher learning (PL 73/1999) and the second is a bill which proposes the establishment of a Statute for Racial Equality (PL 3.198/2000).

The first bill which is still to be debated in Congress extends racial quotas to all federal universities. Each university would distribute places to Indians, Blacks and Whites in accordance with their statistical distribution in the State where the 
university is situated. In effect, it will oblige all candidates for federal university places to define their colour/race. The Statute of Racial Equality (SRE) is far more wide-ranging in its aims, containing an Introduction and eleven chapters, covering rights to health, education, belief, employment and fair pay, justice, and representation in the media ${ }^{15}$. Throughout the document Brazil is presented as a country of two races: on the one side, the "Afro-Brazilians ", " people who classify themselves as such and/or as negros, pretos, pardos or analogous definition » (as pessoas que se classificam como tais elou como negros, pretos, pardos ou definição análoga) (Paim 2006, p. 13) and on the other, un-named but logically present, are the «Whites » (Grin 2006). As if to illustrate a document that refers only to Afro-Brasileiros, the cover of the document portrays a smiling black nuclear family of father, mother and daughter, each one with dreadlocks.

Having defined Brazil as a bi-racial society, the Statute claims to be guided by the desire for "reparation, compensation and the inclusion of the victims of inequality and the promotion of racial equality " (reparação, compensação $e$ inclusão das vítimas da desigualdade e a valorização da igualdade racial) (Paim 2006, p. 14). Each chapter exemplifies actions to be taken in each area of social life. Significantly the first chapter ( On the right to health »), establishes essential and supposedly natural differences between black and white bodies, in spite of all evidence on the non-correlation between phenotype and genotype that has been recently demonstrated by Brazilian geneticists (Parra et al. 2003; Pena 2005). This lays the way for justifying the necessity for all citizens to declare their " race/colour » at all encounters with the health system and to alter the curricula of medical faculties to include materials on what are described as « the specific health problems of the afro-brazilian population as transversal themes in the curricula in schools of medicine " ([a]s especificidades da saúde da população afro-brasileira como temas transversais nos currículos dos cursos de saúde) (Paim 2006, p. 17). Having established a « natural » difference between Afro-Brazilians and (presumably) Euro-Brazilians, the Statute proceeds to advocate quotas in universities, in the media, and the workplace. If brought into law, the Statute will oblige all citizens of Brazil to declare their " race or colour » at just about every step in their lives.

\section{BRAZIL IN THE WORLD}

In 1994 I gave a course about Brazilian racial relations in Gothenburg University in Sweden. When I was discussing the ideas of Oracy Nogueira (Nogueira 1991) on the Brazilian classification system, talking about the multiple terms used to describe all the various forms of appearance, I noticed that a blonde student wearing her hair in a braids and looking more like Queen Nzinga than Brunnehilde was becoming redder and redder and ever more agitated. Finally, she 
exploded: « This is ridiculous! This is not possible! How can this be? » and other phrases that expressed her shock and anger. My attempt to win her over to what could be called a more " anthropological » perspective failed. She refused to be convinced that what I was trying to describe could be taken seriously.

This seemingly banal event drew my attention to the fact that Brazil's various taxonomies are perceived to be outrageous (Judith Butler would doubtless use the term « object ») by those who are accustomed to tidy " racial » categories, that is most of the world, especially that great part which is dominated by the thinking of (mainly Anglophone) societies whose colonial past was based on premises of racial and ethnic segregation, and whose post-colonial present celebrates multiculturalism ${ }^{16}$.

Some years back, Loïc Wacquant and Pierre Bourdieu argued that Brazil was the victim of North American cultural imperialism which was imposing a bipolar racial taxonomy on Brazil. "L'impérialisme culturel repose sur le pouvoir d'universaliser les particularismes liés à une tradition historique singulière en les faisant méconnaître comme tels » (Bourdieu and Wacquant 1998, p. 109).

Le fait que la sociodicée raciale (ou raciste) ait pu, au cours des dernières années, se "mondialiser", perdant du même coup ses caractéristiques de discours justificateur à usage interne ou local, est sans doute une des attestations les plus exemplaires de l'empire et de l'emprise symboliques que les États-Unis exercent sur toute espèce de production savante et surtout demi-savante, à travers notamment le pouvoir de consécration qu'ils détiennent et les profits matériels et symboliques que procure aux chercheurs des pays dominés par l'adhésion plus ou moins assumée ou honteuse au modèle venu des ÉtatsUnis. (ibid., p. 113)

It is true that at least one American foundation has been very generous in its support of non-governmental organisations directed by the most articulate black leaders in Brazil, not to mention its equally generous support for the Brazilian Anthropological Association in its work related to the recognition of the authenticity of indigenous groups and « quilombo communities ». However, Bourdieu and Wacquant could also have highlighted the growing influence of multi-lateral associations, especially the United Nations. Convention 169 on Indigenous and Tribal Peoples in Independent Countries approved by the International Labour Organisation (ILO) on 7/6/1989, and to which Brazil is a signatory, guarantees rights over land and over their own identity « to tribal peoples in independent countries, whose social, cultural and economic conditions distinguish them from other sectors of the national collectivity, and which are governed, totally or partially, by their own customs or traditions, or by special legislation " and " the peoples of independent countries considered indigenous by the fact that they descend from populations who inhabited the country or a geographic region belonging to the country at the time of conquest, or colonisation, or the establish- 
ment of the current state frontiers and who, irrespective of their legal situation, preserve all their own social, economic, cultural and political institutions, or part of them ». "The consciousness of their indigenous or tribal identity must be considered as a fundamental criterion to determine the groups to which the provisions of this Convention apply ». Three years after the publication of the article of Bourdieu and Wacquant, the United Nations held the Third United Nations World Conference Against Racism, Racial Discrimination, Xenophobia and Related Intolerance in Durban, South Africa in October 2001 in which 170 States and 1000 NGOs participated. It had the catalysing effect of propelling the demand for affirmative action in Brazil. The 2004 PNUD report on human development had the sub-title: "Cultural Liberty in a Diversified World». The message of this Report, despite recognising the dangers of the " essentialisation " of culture, is that without cultural diversity there is no development. There is no doubt, therefore, that Brazil has found itself in a network of international relations that is positioned against the old Brazilian ideology of ignoring " race " in the distribution of justice and the largesse of the State. The international conventions are invoked frequently by those in favour of quotas with the clear intention of corroborating the ubiquity and therefore naturalness of aflirmative action.

Seen in this way, then, the power of the wider world to further the naturalization of a bipolar taxonomy is difficult to underestimate. But it would be fallacious to suggest that it introduces a bipolar taxonomy, which we have shown to be consistently present in Brazilian discourse at least since the end of the 19th century. What it is possible to argue, however, is that the massive presence of the wider world which utilizes predominantly Anglo-Saxon terminologies, plays a significant role in adding to the natural truth of the division of Brasil into negros and brancos; a truth « masked » by « miscegenation » and the « myth of racial democracy ».

\section{THE FUTURE}

The notion of racial quotas and the Statute of Racial Equality define Brazil as a society divided between negros and not negros. It brings a legal seal to the gradual growth in salience of a binary racial taxonomy which we have documented in this paper. If the two laws are approved, citizens who visit health centres or compete with one another for university places or positions in the civil service or jobs in the private sector will be obliged by law to classify themselves in one of two categories. The taxonomy of the black activists will have become law.

What will be the consequences of the involvement of the State in the sphere of racial taxonomies and classifications? Will it signify the final victory of the bipolar taxonomy and, as some fear, a growing racialization? After all, the recent 
history of State intervention in racial classification hardly leads to optimism on this score. Or will the new laws have little effect on daily life which will continue to invoke one or other taxonomy in the endless and complex process classification of self and others? Will the new laws impinge upon the subjectivities of Brazilian citizens, strengthening and legitimizing a negro identity, and, by logical extension, a branco one also? Or, as some claim, will the law be "assimilated » by the tradition of hybridism and terminological confusion? ${ }^{17}$

I do not wish to reply to these questions, amongst other reasons because I am well aware that the social sciences are more proficient in interpreting the past that in predicting the future. Even so, one might return to Durkheim and Mauss for inspiration. Almost at the end of their essay they point to the speculative character of primitive classification:

Les choses n'y sont pas simplement disposées sous la forme de groupes isolés les uns des autres, mais ces groupes soutiennent les uns avec les autres des rapports définis et leur ensemble forme un seul et même tout. De plus, ces systèmes, tout comme ceux de la science, ont un but tout spéculatif. Ils ont pour objet, non de facilitier l'action, mais de faire comprendre, de rendre intelligibles les relations qui existent entre les êtres. (Durkheim and Mauss 1968, p. 82)

In the situation I have described, the two rival taxonomies could be seen as speculations on the aesthetic, cultural, economic and political diversity of Brazil. The dispute over taxonomies has certainly produced an unprecedented debate on the nature of Brazilian society. Even so, it is quite evident that the adoption of one or other of these taxonomies is less a case of speculation than of political expedience. Furthermore, the debate is emotionally charged. Defendants of quotas accuse their critics of racism, cynicism and the use of guile to preserve their privilege as a " white elite ». Those who oppose them argue that they merely legalise categories which would be better left to find their own direction in the course of everyday social life. To address inequality between darker and lighter skinned Brazilians, they argue, policies could be directed, as in France, to territories that are predominantly darker and poorer without incurring the legalization of racial categories. What may not be clear to all concerned is that the adoption of the quota law and the Statute of Racial Equality lend the force of law to a bipolar taxonomy which will certainly involve distinct even if not clearly defined practical consequences. *

* Manuscrit reçu en octobre 2007, accepté pour publication en septembre 2008.

\section{NOTES}

A first version of this paper was written in collaboration with Professor Yvonne Maggie, and presented at the XXIII Annual Meeting of the National Association of Social Science Programs, Caxambu, 21-25 October 2003. I am more than grateful to Yvonne Maggie for her constant 
support and lively participation in the debate. I also thank my fellow members of the Observa project (www.observa.ifcs.ufrj.br), in particular Fabiano Dias Monteiro and Durval dos Anjos. My graduate and undergraduate students working on related issues, Robson Cruz, Bruno Chiappetto, Orlando Calheiros and Rafael Wagner have been a source of comfort and ideas.

1. Throughout this essay the terms for color/racial categories are presented in Portuguese in an attempt to avoid distortions through translation into categories which may have distinct meanings in English or French.

2. "À prima facie, pode-se distinguir na populaşão brasileira atual, uma grande maioria de mestiços em graus muito variados de cruzamento, e uma minoria de elementos antropológicos puros, não cruzados. [ em nota " o termo puro tem aqui apenas um valor relativo e se opõe tão somente ao mestiçamento que assistimos.]".

3. "Produto do cruzamento do branco com o negro, grupo muito números, constituindo quase toda a população de certas regiōes do pais ».

4. "Produto do cruzamento das três raças e proveniente principalmente do cruzamento do mulato com o indio, ou com os mamelucos caboclos. Este mestiço, que, no caso de uma mistura equivalente das três raças, devia ser o produto brasileiro por excelência, é muito mais numeroso que realmente se supõe ».

5. For a description and analysis of the taxonomies of Edgar Roquette-Pinto and his followers, see Cunha (2002).

6. "Assim, se é verdade, como diz Myrdal, que no dia em que os sindicatos trabalhistas nos Estados Unidos, em nome da solidariedade de classes, liquidarem em suas fileiras a linha de cor, isto produzirá um estrondo que será ouvido no mundo inteiro e determinará rumos surpreendentes à civilização norteamericana, também aqui se pode dizer, em face da opiniào corrente no mundo a respeito da situação racial brasileira, que estrondo não menor se produziria no Brasil se algum dia as grandes massas de cor deste Pais dessem ouvidos aos chamamentos dessa ideologia de raça e enveredassem pelos caminhos sem saida que ela lhes apontam. "

7. "[D Jesigna-se como não-brancos a soma do que os censos e a PNAD categorizam como pretose pardos, exchindo-se a categoria "amarelos". Em todas as dimensões analisadas, os pardos ocupam uma posiçào intermediária entre brancos e pretos, se bem que essa posição esteja sempre mais próxima do grupo preto ».

8. "Se os processos de competição social calcados no mecanismo de mercado envolvidos no processo de mobilidade social individual operam em detrimento do grupo racialmente subordinado, entâo o enfoque da analise deve se orientar para as formas de mobilização politica dos não-brancos e para o conflito inter-racial. O efeito da rạ̧a sobre a estrutura de classes e a evolução das desigualdades raciais dependerá da emergência de movimentos raciais e das formas assumidas por estes, bem como da forma como os movimentos raciais se ligam a outras lutas e movimentos sociais ».

9. "Ora, é óbvio para qualquer um que os $39 \%$ de pardos do censo de 2000 se compõem em boa parte de descendentes de indigenas. Ai está, aliás, a razào de ser do tribunal racial da Universidade de Brasilia, destinado a apontar entre os pardos os afro-descendentes. A Pesquisa Mensal de Emprego do IBGE, de 1998, mostrou que as pessoas classificadas como pardas pelos critérios impostos, quando deixadas livres para se autoclassificarem se disseram morenas e morenas claras em $60 \%$ dos casos. Apenas $34 \%$ dos pardos concordaram com essa classificaşào e apenas $2 \%$ se disseram mulatos. Pesquisa feita na Regiào Metropolitana do Rio de Janeiro em 1997 revelou que $50 \%$ dos que foram classificados de pardos pelos entrevistadores se disseram morenos ou brancos. Outra pesquisa no Rio, de 2000, mostrou que $48 \%$ dos pardos diziam ter antecedentes indigenas. Nos estados do Norte, onde foi fraca a presença da escravidão africana, os descendentes de indigenas formam sem dúvida a grande maioria dos pardos $"$.

10. "No uso de certas palavras encontramos várias dificuldades. O termo "preto" sempre foi usado pelo "branco" para designar o negro e o mulato em São Paulo, mas através de uma imagem estereotipada e sumamente negativa, elaborada socialmente no passado. Os próprios negros e mulatos preferiram, em suas primeiras manifestações de autonomia - através dos movimentos reivindicatórios - a autodesignação contida na palavra negro. Doutro lado, impugnam o vocabulário "branco", alegando que a mestiçagem impõe restriçōes severas às pretensões de "pureza de sangue" dos paulistas. Para evitar suscetibilidade ou 
recriminaçòes, usamos a palavra "preto" quando a estereotipação do 'branco' entra, visivelmente em jogo, e colocamos todas as palavras entre aspas, com exceção dos casos concretos, onde pudemos discernir as gradações da cor da pele dos sujeitos da investigação. Outrossim, empregamos as expressões "homens de cor" e "população de cor" freqüentemente e sem nenhuma conexão pejorativa ».

11. See e.g. Hanchard (2001) and Sheriff (2001). For a discussion of in-built ethnocentrism in the study of « race » in Brasil, see Fry (1995).

12. "... [a lei representa] o começo de um processo que, dentro das tensòes raciais existentes e em agrasamento neste Pais, não será surpreendente se conduzir à situação que caracteriza as relações de raças nas cidades setentrionais dos Estados Unidos e que se pode resumir na fórmula separate but equal. De fato, até então, no Brasil, na legislação republicana, o negro vinha comparecendo como o liberto de 1888 , como cidadão, em abstrato, juridicamente igual a todos os cidadãos; estava na lei por exclusão - todos são iguais perante a lei, independentemente de cor, sexo, religião, etc. Agora, pela primeira vez, salvo engano, regulamenta-se em lei o comportamento de brancos em relação a negros, e atribui-se a estes, como negros, o direito especifico de não terem praticamente negados alguns direitos mais gerais que a lei já atribuia a todos os cidadãos, independentemente da condição étnica. [...] a declarar que são puniveis os que violarem determinados principios já solenemente presentes em leis anteriores e mais gerais... ".

13. "Ora, uma tal atitude da lei... pode vir a ser... o prelúdio de uma outra legislaçào substitutiva desta $e$ até inspirada no desejo de remediar sua inoperância pratica, visando assegurar a negros e brancos o direito de terem educaçào, recreação, distritos residenciais, obras de assistência e outro setores institucionalizados da vida social iguais mas separados. Para isto, tecnicamente, uma das pré-condições já existe: a entidade jurídica negro, presente no espírito e no texto da legislação ordinária ».

14. http://www.planalto.gov.br/seppir/, accessed on September 4, 2006.

15. The chapters are: "On the rights to health ", "On the rights to education culture, sport and leisures », " On the rights to freedom of conscience and belief and on the free exercice of religious cults ", " On the financing of the promotion of racial equality ", "On the rights of the Afro-Brazilian woman ", " On the rights of descendants of maroon community to their lands ", " On the labour market ", "On the quota system ", "On the media », "On permanent watchdogs in legislative assemblies " and " On access to justice ».

16. In a previous paper I compared British and Portuguese colonial enterprises, formally segregationist and assimilationist, suggesting that the adoption of racial distinctiveness in Brazil might be seen as a final victory of the British colonial doxa as set out by Lord Alfred Lugard (Fry 2000).

17. Anne-Marie Losonczy (2006) observed in her critique of this paper that the phenomenon I describe for Brazil occurs throughout Latin America, above all with incorporation of indigenous identities in constitutions and laws.

\section{REFERENCES CITED}

Bastide Roger and Florestan Fernandes

1971 Brancos e Negros em São Paulo, Anhembi, São Paulo.

BOURDIEU Pierre and Loïc WACQUANT

1998 "Les ruses de la raison impérialiste », Actes de la Recherche en Sciences Sociales, 121-122, pp. 109-118.

Carvalho José Murilo de

2004 "Genocídio racial estatístico », O Globo, p. 7, Rio de Janeiro.

Costa Pinto Luis de Aguiar

1953 Onegro no Rio de Janeiro: relações de raças numa sociedade em mudança, Companhia Editora Nacional, São Paulo. 


\section{Cunha Olívia Maria Gomes da}

2002 Intenção e gesto: pessoa, cor e a produção cotidiana da (in) diferença no Rio de Janeiro, 1927-1942, Arquivo Nacional, Rio de Janeiro.

Degler Carl

1986 Neither Black nor White: slavery and race relations in Brazil and the United States, University of Wisconsin Press, Madison.

Dias Monteiro Fabiano

2003 Retratos em branco e preto, retratos sem nenhuma cor: a experiência do disque-racismo da Secretaria de segurança pública do Estado do Rio de Janeiro, mestrado, UFRJ, Rio de Janeiro.

DURKHEIM Émile and Marcel MAuSS

1968 «De quelque formes primitives de classification. Contribution à l'étude des représentations collectives » [1903], in Marcel Mauss, Euvres. 2. Représentations collectives et diversité des civilisations, Les éditions de Minuit, coll. « Le sens commun », Paris, pp. 13-105.

ENDERS Armelle

2006 «La mise au point d'une machine infernale ? Commentaire à propos de l'intervention de Peter Fry, "The politics of 'racial' classification in Brazil" " "Actes du colloque Des catégories et de leurs usages dans la construction sociale d'un groupe de référence: "Race », " ethnie 》 et " communauté » aux Amériques, CNRS/EHESS, MASCIPO, Paris.

\section{FERNANDES Florestan}

1978a A integração do negro na sociedade de classes, vol. 1, Editora Ática, São Paulo.

1978b A integração do negro na sociedade de classes: o legado da "raça branca 》, vol. 2, Editora Ática, São Paulo.

FreYre Gilberto

1933 Casa grande e senzala, Maia \& Schmidt, Rio de Janeiro.

FRY Peter

1995 "O que a cinderela negra tem a dizer sobre a "Política Racial" no Brasil », Revista USP, 28, pp. 122-135.

2000 "Cultures of difference: the aftermath of Portuguese and British colonial policies in Southern Africa ", Social Anthropology, 8 (2), pp. 117-144.

2004 "A lógica das cotas raciais », $O$ Globo, p. 7, Rio de Janeiro.

Gobineau Joseph Arthur

1853-1855 Essai sur l'inégalité des races humaines, Libraire de Paris, Paris.

Grin Monica

2006 «Estatuto da igualdade racial: uma questão de princípio », Ciência Hoje, 38 (224), pp. 56-58.

HANCHARD Michael G.

2001 Orfeu e poder-Movimento negro no Rio e São Paulo, Ed. UERJ, Rio de Janeiro. 


\section{HaRris Marvin}

1951 "Les relations raciales dans le Brésil rural », in Charles Wagley (ed.), Races et classes dans le Brésil rural, UNESCO, Paris.

1970 "Referential ambiguity in the calculus of Brazilian racial identity », in Dorothea S. Whitten, Norman E. Whitten Jr and John F. Szwed (eds), Afro-American anthropology: Contemporary perspectives, Free Press, New York.

Hasenbalg Carlos

1979 Discriminação e desigualdades raciais no Brasil, tanslated by P. Burglin, Graal, Rio de Janeiro.

1988 "Raça e mobilidade social ", in Carlos Hasenbalg and Nelson do Valle Silva (eds), Estrutura social, mobilidade e raça, pp. 164-182, IUPERJ/ Vertice, Rio de Janeiro [1985].

\section{HeNRIQues Ricardo}

2001 Desigualdade racial no Brasil: evolução das condições de vida na década de 90, Instituto de Pesquisa Econômica Aplicada, Rio de Janeiro.

HERTZ Robert

1980 "A Preeminência da Mão Direita », Religião e Sociedade, 6, pp. 99-125.

Losonczy Anne-Marie

2006 "Comparative remarks on Peter Fry's paper from the Colombian case », Actes du colloque Des catégories et de leurs usages dans la construction sociale d'un groupe de référence : " Race », " ethnie » et " communauté » aux Amériques, CNRS/EHESS, MASCIPO, Paris.

\section{MAGgie Yvonne}

2005 "Mário de Andrade ainda vive? O ideário modernista em questão », Revista Brasileira de Ciências Sociais, 20 (58), pp. 5-25.

MAgGIE Yvonne and Peter Fry

2002 "Le débat qui n'a pas eu lieu: les quotas pour les Noirs dans les universités brésiliennes ", Cahiers du Brésil contemporain, 49/50, pp. 167-182, Paris.

\section{MAIO Marcos Chor}

1997 A história do projeto Unesco: estudos e ciências sociais no Brasil, Instituto Universitário de Pesquisas do Rio de Janeiro (IUPERJ), Rio de Janeiro.

Maio Marcos Chor and Ricardo Ventura SAntos

2005 «Políticas de cotas raciais, os olhos da sociedade e os usos da antropologia: o caso do vestibular da Universidade de Brasília (UnB) », Horizontes Antropológicos, 23, pp. 181-214, Porto Alegre.

\section{NOBLEs Melissa}

2002 "Racial categorization and censuses », in David I. Kertzer and Dominique Arel (eds), Census and identity: the politics of race, ethnicity, and language in national censuses, pp. 43-70, Cambridge University Press, Cambridge. 


\section{NogueIRa Oracy}

1991 «Preconceito Racial de Marca e Preconceito Racial de Origem (Sugestão de um Quadro de Referência para a Interpretação do Material sobre Relações Raciais no Brasil) », Tanto Preto quanto Branco: estudo de relações raciais, T. A. Queiroz, São Paulo [1954].

Paim Paulo 2006 Estatuto da igualdade racial, Senado Federal, Brasília.

Parra Flavia C., Roberto C. Amado, José R. Lambertucci, Jorge Rocha, Carlos M. Antunes and Sérgio D. J. PenA

2003 "Color and genomic ancestry in Brazilians », Proceedings of the national academy of sciences of the United States of America, 100, pp. 177-182.

Pena Sérgio D. J.

2005 " Razões para banir o conceito de raça da medicina brasileira », História ciências Saúde Manguinhos, 12 (2), pp. 321-346.

\section{RoDRIGUES Raymundo Nina}

1894 As raças humanas e a responsabilidade penal no Brasil, Editora Guanabara, Rio de Janeiro.

\section{ROQUETTE-PINTO Edgar}

1933 Ensaios de antropologia brasiliana, Companhia Editora Nacional, São Paulo.

SAHLins Marshall

1977 «Colors and cultures », Semiotica, n 16, pp. 1-22.

SAles A. d. S.

2006 "Who is black in Brazil? A timely or a false question in Brazilian race relations in the era of affirmative action? ", Latin American Perspectives, 33, pp. 30-48.

SANTOS Ricardo Ventura

2004 "Uma grande fraude », O Globo, p. 7, Rio de Janeiro.

SHERIFF Robin E.

2001 Dreaming equality. Color, race and racism in urban Brazil, Rutgers University Press, New Brunswick, New Jersey and London.

SKIDMORE Thomas

1993 Black into white: race and nationality in Brazilian thought, Duke University Press, Durham [1974].

WAGLEY Charles (ed.)

$1951 \quad$ Races et classes dans le Brésil rural, UNESCO, Paris. 